\title{
Editorial: Siliceous plankton biomineralization, biodiversity and evolution
}

The papers included in this thematic issue were presented in the last two meetings of the Silicofossil Group of The Micropalaeontological Society (TMS; Lille in 2011; Cambridge in 2013). The variety and scope of work presented at these meetings highlights the breadth of research within the silicofossil community. The Silicofossil Group emerged within TMS in the early 2000s mainly because of Diatom and Radiolarian specialists and has organized some successful biannual joint meetings with the Palynology Group of TMS. The TMS Silicofossil Group is unique as it encompasses several taxonomic groups that share the physiological adaptation of using silica to synthesize skeletal forms. As such, silica biomineralization is a common area of interest to the members of the Silicofossil Group, including factors controlling growth, morphology and preservation of siliceous microfossils. This encompasses diverse themes including physiology, taxonomy, evolution, genetics and ecology, and application-based topics related to, for example, biochemical engineering, palaeoceanography, palaeolimnology, biostratigraphy and palaeobiology, ranging from molecular-scale (genetics, physiology, etc.) to global-scale (geochemical cycling, biodiversity, etc.) studies.

The first silicofossil meeting, 'Geobiology and environments of silica biomineralizers', was held in Lille (September 2011) and turned out to be very international (45 participants from 14 countries) and diverse in its topics: silica biomineralization and biogeochemical cycles, siliceous plankton (diatoms, radiolaria) and (palaeo-) environments, biodiversity dynamics and biotic response to global change, siliceous sediments and their palaeoenvironmental/industrial significance.

The second and most recent meeting, held at the British Antarctic Survey, Cambridge (August 2013) on 'Siliceous organisms: developments, techniques and applications', gathered 22 participants from 9 countries with presentations on a wide range of subjects, including bioengineering, morphometrics, physiology, isotope geochemistry, palaeoecology, palaeoceanography and biostratigraphy, with four of the main silicofossil groups - diatoms, radiolarians, silicoflagellates and sponges - represented.

The set of seven thematic papers included in this issue reflect only part of the range of topics discussed at these meetings. They build on a first thematic issue published in Revue de Micropaléontologie following the Lille meeting (Caulet, 2013; Dumitrica, 2013; Suzuki et al., 2013). The first three of the seven papers in this issue concern diatoms and the remaining four focus on polycystine radiolaria. Summaries of each paper are given below.

The paper by Eileen Cox discusses the various factors affecting valve morphology in diatoms, as well as some of the ecological and palaeoecological implications. Based on molecular and reproductive evidence the author considers issues raised by changes in diatom species concepts. The author stresses the importance of understanding the degree of morphological consistency within a taxon, the morphological changes that may take place during size reduction of the frustule and the impact of environmental parameters on the morphological variability of a diatom taxon.

Eduardo Morales and co-authors provide evidence that diatom taxa reported from the Bolivian Altiplano do not occur, or are less common, in this region than previously described. Detailed comparisons with type material show that misidentifications of three pennate diatom taxa are the consequence not only of forcefitting, but also of misidentification of original descriptions and plates. The authors suggest that this is likely to have skewed palaeoecological interpretations and propose that future Andean palaeoecological studies should include detailed taxonomic analysis to better assess the true endemism of the regional flora and confirm the environmental associations of the diatom species.

Claire Allen's paper evaluates whether morphological traits (colony length, valve symmetry and aspect ratio) in the Antarctic marine diatom Eucampia antarctica offer potential as quantitative proxies for palaeoceanographic reconstructions. Detailed morphometric data reveal that the aspect ratio of Eucampia antarctica responds independently to symmetry and colony structure and that the ratio of symmetrical to asymmetrical valves offers the strongest potential as a quantitative proxy for austral summer sea surface temperature.

The set of papers on radiolaria offers new insights on siliceous biomineralization in living taxa and presents various aspects concerning the palaeobiodiversity and evolution of Palaeozoic Radiolaria.

Using staining techniques to reveal silica deposition sites in three living species of polycystine radiolaria, Kaoru Ogane and co-authors present the results of their direct observations of silica secretion, as indicated by the emission of fluorescent light. In support of their 'pseudopodial silica absorption hypothesis' the authors provide intriguing evidence that silica is secreted within the pseudopodia and promptly transferred inwards to the cytocalymma to be deposited on the existing skeleton.

The contribution by Lauren Pouille and co-authors describes the biodiversity of a well-preserved upper Darriwilian (upper Middle Ordovician) radiolarian assemblage extracted from carbonate rocks of Kazakhstan. It shares only a few species with a slightly younger assemblage described previously from Kazakhstan and we do not yet know whether this difference is due to evolutionary or palaeoecological/palaeoeanographic reasons. This study provides further evidence that Ordovician radiolarian diversity was relatively high in the upper Darriwilian, in parallel with the trend observed in other well-known planktonic groups (i.e. acritarchs, graptolites).

Martin Tetard and co-authors present Lower Silurian radiolaria obtained from organic-rich black radiolarian cherts that crop out in NW France. This paper is a valuable addition to the rare studies of Lower Silurian radiolaria from middle/high latitudes. Of particular interest is the number of species identified in the studied assemblage that are common in Lower Silurian assemblages known from the low latitudes (Alaska, Nevada, etc.). In addition to improvement of the 
known age range of some of the identified species, this study is important in terms of lower Silurian radiolarian palaeobiogeography.

Based on abundant and well-preserved assemblages of radiolaria obtained after high-resolution sampling of middle Permian sequences in China, Lei Zhang and co-authors discuss the taxonomy, age range and evolutionary relationships of 25 species belonging to three genera of Albaillellarian radiolaria. Their study results in an improved continuous Middle Permian radiolarian biozonation and a revised stratophenetic model of evolution for the various phyletic lineages of the genus Follicucullus, from its first appearance to its extinction.

\section{ACKNOWLEDGEMENTS}

We would like to take this opportunity to thank all the authors who have contributed to this thematic issue, as well as the many reviewers who generously gave their time and insights to help us improve the quality of these publications. Last, but not least, we would like to extend our gratitude to the Editor-in-Chief, Alan Lord, and Production Editor, Sarah Gibbs, for their invaluable editorial help and guidance.

\section{REFERENCES}

Allen, C.S. 2014. Proxy development: A new facet of morphological diversity in the marine diatom Eucampia antarctica (Castracane) Mangin. Journal of Micropalaeontology. First published online July 21, 2014, http://dx.doi.org/10.1144/jmpaleo2013-025.

Caulet, J.P. 2013. George Deflandre (March 18th, 1897, Dizy Magenta (Marne) - June 17th, 1973, Paris). The first French naturalist interested in siliceous microfossils. Revue de Micropaléontologie, 56: 45-50.

Cox, E.J. 2014. Diatom identification in the face of changing species concepts and evidence of phenotypic plasticity. Journal of Micropalaeontology. First published online August 21, 2014, http://dx.doi.org/10.1144/ jmpaleo2014-014.

Dumitrica, P. 2013. Siamese twins and twin-like skeletons in Mesozoic Polycystine Radiolaria. Revue de Micropaléontologie, 56: 51-61.
Morales, E.A., Wetzel, C.E., Rivera, S.F., Van de Vijver, B. \& Ector, L. 2014. Current taxonomic studies on the diatom flora (Bacillariophyceae) of the Bolivian Altiplano, South America with possible consequences for palaeoecological assessments. Journal of Micropalaeontology. First published online August 21, 2014, http://dx.doi.org/10.1144/ jmpaleo2014-007.

Ogane, K., Suzuki, N., Tuji, A. \& Hori, R.S. 2014. Pseudopodial silica absorption hypothesis (PSA hypothesis): a new function of pseudopodia in living radiolarian polycystine cells. Journal of Micropalaeontology. First published online July 21, 2014, http://dx.doi.org/10.1144/ jmpaleo2013-028.

Pouille, L., Danelian, T. \& Popov, L.E. 2014. A diverse Upper Darriwilian radiolarian assemblage from the Shundy Formation of Kazakhstan: insights into late Middle Ordovician radiolarian biodiversity. Journal of Micropalaeontology. First published online September 10, 2014, http://dx.doi.org/10.1144/jmpaleo2014-008.

Suzuki, N., Ogawa, K., Ogane, K. \& Tuji, A. 2013. Patchwork silicification and disposal activity of siliceous fragments of a polycystine radiolarian. Revue de Micropaléontologie, 56: 63-74.

Tetard, M., Danelian, T. \& Noble, P. 2014. Biostratigraphical and palaeobiogeographical implications of Lower Silurian Radiolaria from black cherts of the Armorican Massif (France). Journal of Micropalaeontology. First published online August 21, 2014, http://dx.doi.org/10.1144/ jmpaleo2014-013.

Zhang, L., Ito, T., Feng, Q., Caridroit, M. \& Danelian, T. 2014. Phylogenetic model of Follicuccullus lineages (Albaillellaria, Radiolaria) based on high-resolution biostratigraphy of the Permian Bancheng Formation, Guangxi, South China. Journal of Micropalaeontology. First published online September 10, 2014, http://dx.doi.org/10.1144/jmpaleo2014-012.

Taniel Danelian ${ }^{1} \&$ Claire S. Allen ${ }^{2}$ ${ }^{1}$ Department of Earth Sciences, University Lille 1, CNRS-UMR 8217 Géosystèmes, Cité Scientifique, SN5, 59655 Villeneuve d'Ascq, France ${ }^{2}$ British Antarctic Survey, High Cross, Madingley Road, Cambridge CB3 0ET, UK 